\title{
Assessing Crop and Water Productivity Performance of Different Crops and Cropping Systems
}

\author{
Ramesh Kumar, R.S. Yadav, Amit Kumawat, Vinay Nangia ${ }^{1}$, N.D. Yadava ${ }^{2}$, V.S. Rathore ${ }^{2}$
}

10.18805/ag.D-5481

\begin{abstract}
Background: Freshwater in sufficient quantity and adequate quality is a prerequisite for human societies and natural ecosystems. To adequately feed 9.3 billion people in 2050 , consumptive water use (i.e. transpired water) by all food and fodder crops needs to increase from its present estimated level of $7000 \mathrm{~km}^{3} /$ year to $12,586 \mathrm{~km}^{3} /$ year. However, fresh water resources are increasingly getting scarce because of increased competition among a multitude of users. Getting agriculture to perform with progressively smaller allocation of renewable water resources will remain a challenge on global scale. To meet the challenge there is an urgent need to improve the crop water productivity to ensure the sustainability of agriculture.

Methods: An experiment was carried out at village Menawali, Hanumangarh, Rajasthan during both kharif and rabi seasons to assess productivity, economics, N-uptake and water use of different crops. An area of 187 ha comprising 25 farmers irrigated by common irrigation channels were selected to collect the information. The information required i.e. soil, crop management, growth, phonological, yields, water balance, N-uptake and water use efficiency of each crops were collected from 15 farmers. Bt-cotton and clusterbean of kharif and wheat and Indian mustard in rabi were prominent crops, cotton-wheat, cotton-mustard, clusterbean-wheat and clusterbeanmustard were major cropping sequences of the study region.

Result: In kharif season, Bt-cotton gave higher economic yields than clusterbean and amongst rabi season crops, economic yields of wheat and mustard were $4255,1778 \mathrm{~kg} / \mathrm{ha}$, respectively. The economic yield of cropping sequences varied from $3741-6514 \mathrm{~kg} / \mathrm{ha}$ and were higher for cotton-wheat $(6218 \mathrm{~kg} / \mathrm{ha})$, intermediate for clusterbean-wheat $(5785 \mathrm{~kg} / \mathrm{ha})$ and lower for cotton-mustard (3741 kg/ha) and clusterbean-mustard $(3308 \mathrm{~kg} / \mathrm{ha})$. The cotton-wheat $(₹ 1181.2 \mathrm{~mm})$ sequence had highest water use. Clusterbean-wheat cropping system recorded highest water productivity $(16.5 \mathrm{~kg} / \mathrm{ha} \mathrm{mm})$ followed by clusterbean-mustard $(14.9 \mathrm{~kg} / \mathrm{ha} \mathrm{mm})$. The clusterbeanmustard (₹456/ha mm) cropping sequence was most profitable and fetched highest net return followed by clusterbean-wheat (₹383/ha $\mathrm{mm}$ ).
\end{abstract}

Key words: Cotton, Clusterbean, Growth, Phenological, Water balance.

\section{INTRODUCTION}

Agriculture is the largest user of water with $65-75 \%$ of freshwater being currently used for irrigation (Bennett, 2000, Prathapar, 2000). In some cases, it draws as much as $90 \%$ of the total water. The Food and Agriculture Organization predicted that water withdrawals by agriculture sector will increase by about $14 \%$ during 2000-2030 to meet food demand (FAO, 2006). However, the access of irrigated agriculture to the scarce water resource is under sever threat, because of the increasing water needs due to rapid urbanization, environmental consciousness, recreation and tourism (Perry 2007). Furthermore, the scarcity of water for agriculture are heightened by groundwater mining, escalating cost of developing new irrigation facilities, low water productivity of existing resources, increasing water pollution and degradation of water related ecosystems (Rosegrant et al., 2009). Water productivity, a concept expressing the value or benefit derived from the use of water, includes various aspects of water management and is very relevant for arid and semi-arid regions (Kijne et al., 2003). It can be expressed in terms of grain (or seed) yield per amount of water used in different processes such as transpiration, evapotranspiration and percolation, and provides a proper diagnosis of where and when water could be saved. Increasing water productivity is particularly appropriate
Department of Agronomy, College of Agriculture, Swami Keshwanand Rajasthan Agriculture University, Bikaner-334 006, Rajasthan, India.

${ }^{1}$ Integrated Water and Land Management Programme, International Center for Agricultural Research in the Dry Areas, Jordan.

${ }^{2}$ Central Arid Zone Research Institute, Regional Research Station, Bikaner-334 006, Rajasthan, India.

Corresponding Author: Amit Kumawat, Department of Agronomy, College of Agriculture, Swami Keshwanand Rajasthan Agriculture University, Bikaner-334 006, Rajasthan, India.

Email: amit.agron@gmail.com

How to cite this article: Kumar, R., Yadav, R.S., Kumawat, A., Nangia, V., Yadava, N.D. and Rathore, V.S. (2022). Assessing Crop and Water Productivity Performance of Different Crops and Cropping Systems. Agricultural Science Digest. DOI: 10.18805/ ag.D-5481.

Submitted: 28-08-2021 Accepted: 17-12-2021 Online: 14-01-2022

where water is scarce compared with other resources involved in production. For the rural poor, more productive use of water can mean better nutrition for families, more income and productive employment. Targeting high water productivity can reduce investment costs by reducing the amount of water that has to be withdrawn (Molden et al., 
2010). Higher water productivity reduces the need for additional water and land resources in irrigated and rainfed systems. Enhancing water productivity is thus a critical response to growing water scarcity, including the need to leave enough water in rivers to sustain ecosystems to meet the growing demands of cities and industries (Hengsdijk et al., 2006).

Rajasthan is predominantly a rainfed state and precipitation being major source of annual renewable water supply. The total water resources of state account for 45.09 BCM, consisting $33.94 \mathrm{BCM}$ share by surface water resources and $11.15 \mathrm{BCM}$ by groundwater resources. The overall utilization of water resources is $\sim 81 \%$, being $71 \%$ for surface water and $104 \%$ of groundwater resources. With the fast increasing population the water availability in the state is decreasing at an alarming rate, and water scarcity is growing rapidly. Water scarcity threatens food security for millions of people, particularly in the arid and semi-arid regions. A major constraint to increase the food grain production in arid Rajasthan is limited surface water availability. Furthermore, the current irrigation systems in Rajasthan State are causing environmental problems of rising and declining groundwater levels, water logging and salinization. The Hanumangarh district, located in the North Western part of Rajasthan State, represents the typical example of canal water misuse leading to rising groundwater levels, water logging and secondary salinization. These water management issues are very complex and must be addressed by better planning and management. As the information pertaining to water productivity of different crops are non-existent for IGNP stage-I command area. Drawing on these insights, the present study is planned to assess irrigation performance, agronomic and economic performance of different crops, land and water productivity and quantification of water balance at scheme level was undertaken.

\section{MATERIALS AND METHODS}

An experiment on farmers field was conducted at village Mainawali in Hanumangarh district of Rajasthan $\left(074^{\circ}\right.$ $20^{\prime} 34^{\prime \prime} \mathrm{E}$ to $074^{\circ} 20^{\prime} 60^{\prime \prime}$ longitude and $28^{\circ} 37^{\prime} 62^{\prime \prime} \mathrm{N}$ to $29^{\circ}$ 21'39" N latitude and $235 \mathrm{~m}$ above mean sea level). The soils of the area are alluvial and calcareous in nature formed under arid and semi arid climate. The soils of site are brown to greyish brown and dark grey in colour, besides being calcareous and slightly alkaline in reaction. These soils are fairly deep and have low permeability. Soil sampling with an interval of $0-15,15-25,25-50,50-75$ and $75-100 \mathrm{~cm}$ soil depths, respectively were taken with the help of soil auger crop wise from all the selected farmers fields and were analyzed for physiochemical properties. Soil physical (texture and bulk density) and chemical (pH, EC, CEC, ammonical-nitrogen and nitrate nitrogen) properties of experimental field were determined up to $1.0 \mathrm{~m}$ depth following the standard procedures. The sand, silt and clay contents were determined with Hydrometer method, bulk density with core method, EC was measured with conductivity meter and $\mathrm{pH}$ with $\mathrm{pH}$ meter, $\mathrm{OC}$ by Wet digestion method. Ammonical nitrogen was determined by Nessler's method and nitrate nitrogen was determined by Phenoldisulphonic acid method. The field capacity was determined in the field by covering the fully saturated soil surface with a polythene sheet and measuring the moisture content after 24-72 hours depending on soil type. In order to ascertain the physico-chemical characteristics, soil samples were collected from different spots of the experimental field. The ground water at the experimental site was less than $10 \mathrm{~m}$ deep and was determined with piezometer. The field water balance can be written as $P=E$ $+T+R+D+S-I$ where, $P$ is precipitation, $E$ is soil evaporation, $T$ is crop transpiration, $R$ is surface runoff, $D$ is drainage, $S$ is change in soil water storage and $I$ is irrigation. Water use efficiency (WUE) was calculated as

$$
\text { WUE }(\mathrm{kg} / \mathrm{ha} \mathrm{mm})=\frac{\mathrm{Y}}{\mathrm{ET}}
$$

Where,

WUE represents water use efficiency for the grain yield $(\mathrm{kg} /$ ha), $Y$ is the grain yield and ET is the evapo-transpiration during the growth period.

Selection of farmers was done on the basis of major cropping sequence grown in the study area. A general survey of 28 farmers' fields was done out of which 15 farmers were selected keeping in view the irrigation facilities from the IGNP canal. Total area of the experimental site was 187 ha out of which net cropped area were 170 ha Average land holding of 6.1 ha. Major crops of the area were cotton and clusterbean during kharif and wheat and mustard in rabi. Majority of farmers (about $80 \%$ ) grow cotton and wheat in kharif and rabi season, respectively. About 18-20\% cropped area was under cluster bean and mustard during kharif and rabi season, respectively. In this region there are more than 6 different types of crops grown like: Gossypium hirsutum, Cymopsistetra gonaloba, Pennisetum glaucum, Triticum aestivum, Brassica Juncia, Cicer aeritinum and Hordium vulgare, out of which maximum area is under cotton. Wheat is next most popular crop among farmers living in the region. It was observed that $75 \%$ of the population was engaged in agriculture. The major crop sequences/rotations followed in Menawali region of Hanumangarh district are cotton-wheat for one year rotation.

\section{RESULTS AND DISCUSSION}

\section{Productivity}

The yields of crops varied substantially. Cotton gave higher economic and biomass yields than clusterbean in kharif season crops. Cotton had 28.3 and $27.8 \%$ higher economic and biomass yield than clusterbean. Among the rabi season crops barley out yielded other crops and produced 155.9, 98.5 and $6.9 \%$ higher seed yields than mustard, chickpea and wheat, respectively. With respect to total biomass productivity, barley gave highest biomass yield followed by wheat, chickpea and mustard. The increase in biomass yield 
under barley was to the extent of $97.8,63.9$ and 7.4 over mustard, chickpea and wheat, respectively (Table 1). Under non-stressed conditions, the yield of crop at any given location is determined by the product of the available light energy and by the genetically determined properties: efficiency of light capture [which is function of LAI and canopy architecture (radiation interception coefficient, k)], the efficiency of conversion of the intercepted light into biomass [i.e. radiation use efficiency (RUE)] and the proportion of biomass partitioned into grain [harvest index $(\mathrm{HI})$ ], each describing broad physiological and architectural properties of the crop (Long et al., 2006) and variations in these efficiencies leads to variations in yields of crops. The higher biomass yield of cotton compared clusterbean during kharif season and wheat and barley compared to mustard, chickpea during rabi season in the present study might be explained by longer duration (greater light energy available over crop duration) and higher RUE of cotton and barley compared to other crops in respective seasons. The reported value of RUE (1.18-1.69 $\mathrm{g} / \mathrm{MJ})$ (Sadras, 1996) for cotton is higher compared RUE (0.57-1.21 g/MJ) for clusterbean (1.1$1.5 \mathrm{~g} / \mathrm{MJ}$ ) (Khicher et al., 2012). Similarly, the value of RUE for barley and wheat (1.5-1.7 g/MJ) (Kemanian et al., 2004) is higher compared to RUE for chickpea (0.67 - $1.30 \mathrm{~g} / \mathrm{MJ})$ (Singh and Rama, 1989) and mustard (1.30 - $1.43 \mathrm{~g} / \mathrm{MJ})$ (Jha et. al., 2012). Among kharif season crops, cotton had higher $\mathrm{HI}(26-30 \%)$ compared to clusterbean (22 to $24 \%$ ) and among rabi season crops, wheat and barley had higher $\mathrm{HI}(39-43 \%)$ compared to mustard and chickpea (30 -35\%). Therefore, the differences in seed yield of crops observed in this study may possibly due to differences in biomass yield and harvest index among crops.

The nitrogen content in seed was observed higher in clusterbean and seed yield was higher in cotton however, the cotton (78 kg/ha) and clusterbean (79 kg/ha) gave relatively similar $\mathrm{N}$-uptake during kharif season. Increased uptake of $\mathrm{N}$ seems to be due to the fact that uptake of nutrient is a product of biomass accumulated by particular part and its nutrient content (Singh et al., 2011). Among the rabi season crops barley recorded higher $\mathrm{N}$-uptake than wheat, mustard and chickpea with a tune of $3.0,5.9$ and $1.3 \%$, respectively. Increase in $\mathrm{N}$-uptake by barley crop appears to be due to the accumulative effect of increased yield of seed and straw as well as increased contents of $\mathrm{N}$ in seed and straw. As mentioned earlier, nutrient accumulation in plant is dependent on dry matter accumulation in plant and concentration of nutrient at cellular level (Tripathi et al., 2010). The n-uptake recorded by mustard was lower among all rabi crops. This might be due to the fact that the seed and straw yield as well as nitrogen concentration in seed and straw was found lower as compared to other rabi season crops. Hence, improvement in $\mathrm{N}$ component on account of nitrogen application reflected in higher uptake of nutrients by the crop. These results are in the line with the findings of Kumar et al. (2019) and Deo and Khandelwal (2009).

\section{Water balance and water productivity}

The amount of water applied and water loss were different or varied among different crops and cropping system. Among kharif season crops, the highest water was used by cotton

Table 1: Observed economic, straw yield and aboveground biomass of different crops.

\begin{tabular}{|c|c|c|c|c|c|c|c|c|}
\hline \multirow[t]{2}{*}{ Crops } & \multicolumn{2}{|c|}{$\begin{array}{l}\text { Seed yield } \\
(\mathrm{kg} / \mathrm{ha})\end{array}$} & \multicolumn{2}{|c|}{$\begin{array}{l}\text { Straw yield } \\
(\mathrm{kg} / \mathrm{ha})\end{array}$} & \multicolumn{2}{|c|}{$\begin{array}{l}\text { Aboveground } \\
\text { biomass (kg/ha) }\end{array}$} & \multicolumn{2}{|c|}{$\begin{array}{c}\text { N-uptake } \\
\text { (kg/ha) }\end{array}$} \\
\hline & Range & Mean \pm SD & Range & Mean \pm SD & Range & Mean \pm SD & Range & Mean \pm SD \\
\hline Cotton & $1594-2354$ & $1963 \pm 251$ & $4544-6960$ & $5511 \pm 808$ & $6158-9216$ & $7474 \pm 1040$ & $56.9-94.1$ & $78 \pm 11$ \\
\hline Clusterbean & $1214-1784$ & $1530 \pm 231$ & $3582-5164$ & $4314 \pm 726$ & $4825-6948$ & $5844 \pm 951$ & $56.9-94.6$ & $79 \pm 13$ \\
\hline Wheat & $4010-4513$ & $4255 \pm 182$ & $5367-6102$ & $5788 \pm 286$ & $9439-10658$ & $10043 \pm 417$ & $102.6-17.4$ & $109 \pm 5$ \\
\hline Mustard & $1226-2543$ & $1778 \pm 443$ & $2505-5331$ & $3677 \pm 984$ & $3731-7874$ & $5456 \pm 1424$ & $49.2-101.3$ & $70.6 \pm 18$ \\
\hline Chickpea & $2045-2537$ & $2292 \pm 218$ & $3856-4658$ & $4290 \pm 238$ & 5975-7224 & $6582 \pm 563$ & $106.4-117.3$ & $110.8 \pm 7$ \\
\hline Barley & $4267-4876$ & $4551 \pm 173$ & $5938-6589$ & $6243 \pm 249$ & $10231-11482$ & $10794 \pm 486$ & $108.6-119.8$ & $112.3 \pm 6$ \\
\hline
\end{tabular}

Table 2: Soil water balance components for different crops.

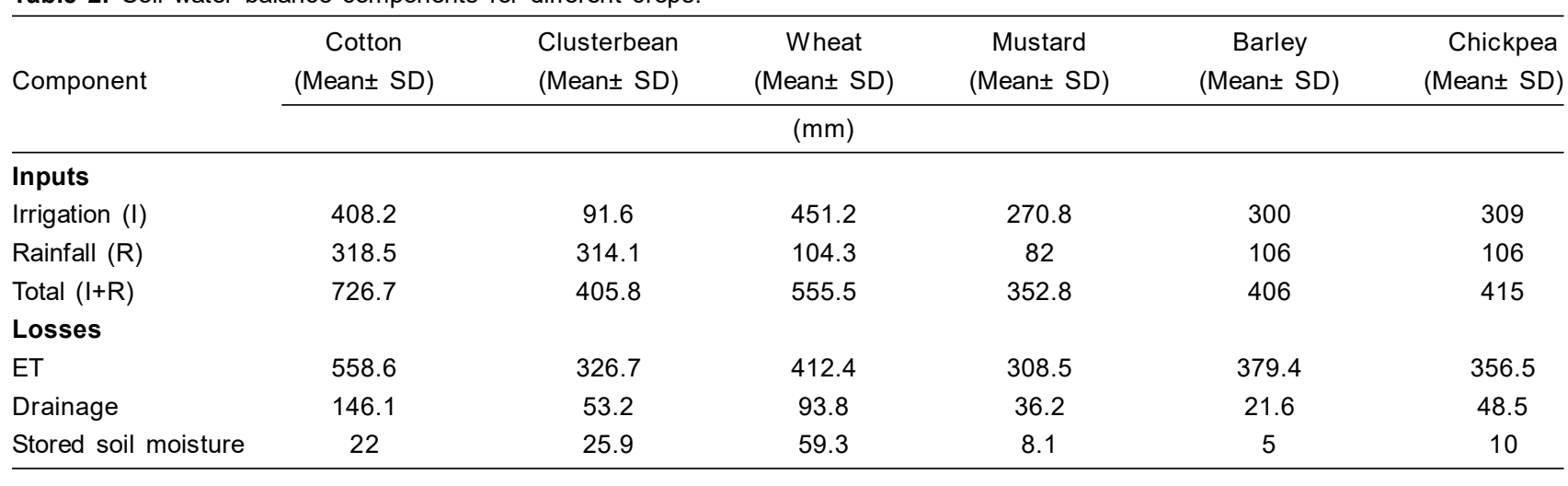


$(726.7 \mathrm{~mm})$ as compared to clusterbean $(405.8 \mathrm{~mm})$. The reported values of water use varied from 610 to $660 \mathrm{~mm}$ for cotton (Anonymous, 2012) and 425 to $654 \mathrm{~mm}$ for clusterbean (Singh and Deo, 1998). The ET and deep drainage loss was also higher in cotton than clusterbean. Among rabi season crops, the water use for wheat $(455.5$ $\mathrm{mm})$ was higher than chickpea $(415.0 \mathrm{~mm})$ and barley $(406.0$ $\mathrm{mm})$ whereas lowest water was used by mustard $(352.8$ $\mathrm{mm}$ ). The ET and deep drainage consisted 77.9 to $93.4 \%$ and $5 \%$ to $20 \%$ share in total water applied (Table 2). The highest water productivity was observed in clusterbean (14.4 and $3.8 \mathrm{~kg} / \mathrm{ha} \mathrm{mm}$ ) both in terms of biological and economic yield compared to cotton (10.3 and $2.7 \mathrm{~kg} / \mathrm{ha} \mathrm{mm}$ ). Water productivity in terms of biological and economic yield was highest in barley ( 26.6 and $11.2 \mathrm{~kg} / \mathrm{ha} \mathrm{mm}$ ) followed by wheat (18.1 and $7.7 \mathrm{~kg} / \mathrm{ha} \mathrm{mm}$ ) whereas the lowest was observed in chickpea (15.9 and $5.5 \mathrm{~kg} / \mathrm{ha} \mathrm{mm})$ and mustard $(15.5$ and $5.0 \mathrm{~kg} / \mathrm{ha} \mathrm{mm}$ ). This presents clusterbean in kharif and barley and wheat in rabi season as highest efficient crops in terms of physical crop production in Hanumangarh district. The differences in water productivity for different crops are due to the differences in the chemical composition, harvest index and evaporative demands during the respective seasons. In Hanumangarh district, temperatures and vapour pressure deficit are high during the kharif (summer) season, which results into high evaporative demands. Consequently, the $W P_{T}, W P_{E T}$ and $W P_{E T Q}$ of summer crops (cotton and clusterbean) are lower than those for winter crop (wheat and barley). Zwart and Bastiaanssen (2004) established global benchmark values of $W P_{\mathrm{ET}}$, expressed as Y/ET $(\mathrm{kg} /$ $\mathrm{m}^{3}$ ), at 1.08 for wheat and 0.63 for cotton. Droogers and Kite (2001) mentioned a value of WP $\mathrm{ET}_{\mathrm{T}}$ from 0.16 to 0.39 for cotton at basin to field level in Turkey. Similarly, a value of $W P_{E T}$ about 0.27 for cotton is mentioned in a study towards on crop water productivity in Pakistan during 1970s (Parc, 1982). Hussain et al. (2003) gave a $W P_{E T}$ value of 1.36 for wheat in Haryana region. In our analysis, the average $W P_{E T}$ at the selected farmer fields in Hanumangarh district was 1.39 for wheat and 0.23 for cotton. To improve the $W P_{E T}$ for a crop, the fraction of soil evaporation $E$ in evapotranspiration ET is important (Bouman and Tuong, 2001).

\section{Cropping system}

Cotton-wheat cropping system recorded highest economic $(6218 \mathrm{~kg} / \mathrm{ha})$ and biomass yield $(17517 \mathrm{~kg} / \mathrm{ha})$ over rest of the systems followed by clusterbean-wheat whereas clusterbean-mustard recorded lowest seed $(3308 \mathrm{~kg} / \mathrm{ha})$ and biomass yield (11300 kg/ha) (Table 3). Cotton-wheat cropping system had $87.9,66.2$ and 7.5 per cent higher economic and 55.0, 35.4 and 10.2 percent higher biomass yield over clusterbean-mustard, cotton-mustard and clusterbean-wheat, respectively. The differences in yields of cropping system reflected differences in yields among component crops of cropping sequences. In term of biomass yield, cotton-wheat cropping system was most productive system and it yielded $4-40 \%$ higher biomass yield compared to other cropping systems. The higher biomass yield of cotton-wheat cropping system may be attributed to higher biomass yield of both cotton and wheat due to longer duration coupled with higher RUE relative to other crops in respective seasons. The higher biomass yield of systems involving wheat (Cotton-wheat, clusterbean-wheat) compared to the systems that involve mustard (Cottonmustard, clusterbean-mustard) might be explained by the higher biomass yield of wheat relative to mustard. These findings agree with Singh et al., (2003) who found that cottonwheat gave higher yields than other cropping systems in Rajasthan. In present study, the cotton-wheat cropping system recorded higher seed yield compared to other cropping system. Higher seed yield reported for cotton-wheat cropping system could possibly be attributed to higher biomass yield and harvest index of cotton and wheat compared to other crops in respective seasons. The lower seed yield of cotton-mustard and clusterbean-mustard cropping system could be attributed to lower biomass and seed yield of mustard compared to wheat (Singh and Deo, 1998; Mayee et al., 2008).

The cost of cultivation of cotton-wheat $(70856 / \mathrm{ha})$ cropping system was higher than other cropping system due to higher cost of cultivation of cotton and wheat compared to other crops. The cost of cultivation for system that included cotton tended to be higher than for comparable systems that include clusterbean due to higher cost of cultivation of cotton. The higher labor, irrigation, seed and plant protection chemicals costs for cotton compared to clusterbean was responsible for higher cost of cultivation of cotton based cropping systems. Clusterbean-wheat cropping system had highest gross return (₹420300/ha) and net return (₹368582/ ha) followed by clusterbean-mustard (₹368582, 346182/ha).

Table 3: Yield and economics of different cropping system.

\begin{tabular}{|c|c|c|c|c|c|}
\hline Cropping system & $\begin{array}{l}\text { Seed yield } \\
\text { (kg/ha) }\end{array}$ & $\begin{array}{l}\text { Biomass yield } \\
\qquad(\mathrm{kg} / \mathrm{ha})\end{array}$ & $\begin{array}{l}\text { Cost of cultivation } \\
\text { (₹ha) }\end{array}$ & $\begin{array}{c}\text { Gross return } \\
\text { (₹ha) }\end{array}$ & $\begin{array}{l}\text { Net return } \\
\text { (₹ha) }\end{array}$ \\
\hline Cotton-Wheat & 6218 & 17517 & 70856 & 175825 & 104954 \\
\hline Cotton-Mustard & 3741 & 12930 & 64437 & 147006 & 82554 \\
\hline Clusterbean-Wheat & 5785 & 15887 & 51718 & 420300 & 368582 \\
\hline Clusterbean-Mustard & 3308 & 11300 & 45299 & 391481 & 346182 \\
\hline Cotton-Barley ${ }^{*}$ & 6514 & 18268 & 73130 & 186056 & 112911 \\
\hline Cotton-Chickpea* & 4225 & 14056 & 69555 & 176272 & 96737 \\
\hline
\end{tabular}

* Cotton-barley and cotton-chickpea cropping system were negligible as they have less than $1 \%$ area in the study site. 
Assessing Crop and Water Productivity Performance of Different Crops and Cropping Systems

Table 4: Water use efficiency of different cropping system.

\begin{tabular}{|c|c|c|c|c|}
\hline \multirow{2}{*}{ Cropping system } & \multicolumn{2}{|c|}{ Yield (kg/ha mm) } & \multicolumn{2}{|c|}{ Return (₹/ha mm) } \\
\hline & Biological yield & Seed yield & Gross return & Net return \\
\hline & \multicolumn{4}{|c|}{ Water use efficiency (in terms of water applied) } \\
\hline Cotton-Wheat & 13.7 & 4.8 & 137.1 & 81.9 \\
\hline Cotton-Mustard & 12.0 & 3.5 & 136.2 & 76.5 \\
\hline Clusterbean-Wheat & 16.5 & 6.0 & 437.2 & 383.4 \\
\hline Clusterbean-Mustard & 14.9 & 4.4 & 516.1 & 456.3 \\
\hline Cotton-Barley* & 16.1 & 5.8 & 164.3 & 99.7 \\
\hline \multirow[t]{2}{*}{ Cotton-Chickpea* } & 12.3 & 3.7 & 152.5 & 91.6 \\
\hline & \multicolumn{4}{|c|}{ Water use efficiency (In terms of water used) WUE } \\
\hline Cotton-Wheat & 18.0 & 6.4 & 181.1 & 108.1 \\
\hline Cotton-Mustard & 14.9 & 4.3 & 169.5 & 95.2 \\
\hline Clusterbean-Wheat & 21.5 & 7.8 & 568.7 & 498.7 \\
\hline Clusterbean-Mustard & 17.8 & 5.2 & 616.3 & 545.0 \\
\hline Cotton-Barley* & 19.5 & 6.9 & 198.4 & 120.4 \\
\hline Cotton-Chickpea* & 15.4 & 4.6 & 190.3 & 114.3 \\
\hline
\end{tabular}

Clusterbean-wheat cropping system had 77.6, 71.5 and 6.0 percent higher net returns over cotton-mustard, cottonwheat and clusterbean-mustard, respectively. Cotton-wheat had higher net return than cotton-mustard. Our findings agree with the findings of Nehra and Bhunia, 2002 who found that cotton-wheat was more profitable than cotton-mustard in Sriganganagar. Higher gross and net return for clusterbean-wheat cropping system than other systems is mainly attributed to better yield of wheat and higher selling price and lower cost of cultivation of clusterbean.

\section{Water use efficiency}

Cotton based cropping system had higher water use than other systems. The highest water use was observed in cotton-wheat cropping system and is attributed to higher water use of cotton and wheat compared to other crops (Table 4). The clusterbean-wheat and clusterbean-mustard had lower water use than other systems due to lower water use for clusterbean than cotton. Considering water use efficiency in physical terms $\left(W \cup E_{B Y}\right.$ and $\left.W U E_{E Y}\right)$, clusterbean-wheat and clusterbean-mustard were more water use efficient system than cotton-wheat and cottonmustard. The higher $W U E_{B Y}$ and $W_{E Y}$ of clusterbean relative to cotton might be responsible for higher WUE of clusterbean-wheat and clusterbean-mustard than cottonwheat and cotton-mustard system. The low yield of mustard might be responsible for lowest $W U E_{B Y}$ and $W U E_{E Y}$ of cottonmustard system. In contrast to yields and WUE in physical terms, the clusterbean-mustard was most water use efficient system in monetary terms $\left(\mathrm{WUE}_{\mathrm{GR}}\right.$ and $\left.\mathrm{WUE}_{\mathrm{NR}}\right)$. The higher water use efficiency of clusterbean-mustard cropping system is attributed to lower water use and higher return due to higher selling price of clusterbean than cotton.

\section{CONCLUSION}

It may be concluded that cotton and wheat produced higher economic and biomass yield than other crops. The cost of cultivation was higher for cotton and wheat than other crops of respective season. Among the tested cropping system, clusterbean-wheat and clusterbean-mustard were more profitable than other cropping system.

\section{ACKNOWLEDGEMENT}

The author is grateful to ICARDA for providing financial assistantship and CAZRI, RRS, Bikaner for providing required facilities to conduct the present research work in ICAR-ICARDA collaborative research project\#8.

\section{REFERENCES}

Anonymous, (2012). Three Decades of Research on Water Management in Canal Command of North Western Rajasthan. All India Coordinated Research Project on Water Management. Agricultural Research Station, SKRAU, Sriganganagar.

Bennett, A.J. (2000). Environmental consequences of increasing production: Some current perspectives. Agric. Ecosys. Environ. 82: 89-95.

Bouman, B.A.M. and Tuong, T.P. (2001). Field water management to save water and increase its productivity in irrigated lowland rice. Agricultural Water Management. 49(1): $11-30$.

Deo, C. and Khandelwal, R.B. (2009). Effect of zinc and phosphorus on yield, nutrient uptake and oil content of mustard grown on the gypsum treated sodic soil. Journal of Indian Society of Soil Science. 50: 472-475.

Droogers, P. and Kite, G. (2001). Estimating productivity of water at different spatial scales using simulation modelling. Research Report 53. International Water Management Institute. Colombo, Sri Lanka.

FAO, (2006). Water Use Efficiency in Agriculture: The Role of Nuclear and Isotopic Techniques. Proceedings FAO/ IAEA,Workshop on Use of Nuclear Techniques in Addressing Soil Water Nutrient Issues for Sustainable Agricultural Production at $18^{\text {th }}$ World Congress of Soil Science, Philadelphia, Pennsylvania, USA, July, 9-15. 
Hengsdijk, H., van der Krogt, W., Verhaeghe, R.J. and Bindraban, P.S. (2006). Consequences of supply and demand management options for integrated water resources management in the Jabotabek-Citarum region, Indonesia. International Journal of River Basin Management. 4(4): 1-8.

Hussain, I., Sakthivadivel, R., Amarasinghe, U., Mudassar, M. and Molden, D. (2003). Land and Water Productivity of Wheat in the Western Indo-Gangatic Plains of India and Pakistan: A Comparative Analysis. Research Report 65, International Water Management Institute, Colombo, Sri Lanka, pp 50.

Jha, S., Sehgal, V.K. and Subbarao, Y.V. (2012). Effect of direction of sowing and crop phenotype on radiation interception, use efficiency, growth and productivity of mustard (Brassica juncea L.). Journal of Agricultural Physics. 12(1): 37-43.

Kemanian, A.R., Stockle, C.O. and Huggins, D.R. (2004). Variability of Barley Radiation-Use Efficiency, Crop Science. 44: 1662-1672.

Khichar, M.L., Ram Niwas and Yadav, B.D. (2012). Impact of radiation and thermal interception on by-product of clusterbean crop under different growing environments, Forage Research. 37(4): 241-244.

Kijne, J., Barker, R. and Molden, D. (2003). Water productivity in agriculture: Limits and opportunities for improvement. Comprehensive assessment of Water Management in Agriculture, Series No. 1, CABI press, Wallingford, UK, pp. 352.

Kumar, R., Yadav, R.S., Kumawat, A., Rathore, V.S., Yadava, N.D and Nangia, V. (2019). Evaluation of cropsyst model for yield and water productivity of chickpea. Indian Journal of Agricultural Research. 53(4): 463-467.

Long, S.P., Zhu, X.G., Naidu, S.L. and Ort, D.R. (2006). Can improvement in photosynthesis increases crop yields? Plant, cell and Environment. 29: 315-330.

Mayee, C.D., Monga, D., Dhillon, S.S., Nehra, P.L. and Pundir, P. (2008). Cotton-Wheat Production System in South Asia: A success Story. Asia-Pacific Association of Agricultural Research Institutes, Bangkok, Thailand.

Molden, D., Steduto, P., Bindraban, P., Hanjra, M.A. and Kijn, J. (2010). Improving agricultural water productivity: Between optimism and caution. Agricultural Water Management. 97: 528-535.
Nehra, P.L. and Bhunia, S.R. (2002). Yield, economics and sustainability of cotton based cropping system in irrigated north-west Rajasthan. Journal of Cotton Research Development. 16: 29-31.

Parc (1982). Consumptive use of water for crops in Pakistan, Pakistan Agricultural Research Council, Final Technical report: PK-ARS-69/FG Pa 251, Islmabad, Pakistan, pp. 193.

Perry C. (2007). Efficient irrigation; inefficient communication; flawed recommendations. Irrigation and Drainage Systems.56: 367-378.

Prathapar, S.A. (2000). Water shortages in the $21^{\text {st }}$ century. In: Cadman, H. (Ed.), Food and Environment Tightrope. Australian Centre for International Agricultural Research, Canberra, Australia, pp. 125-133.

Rosegrant, M.W., Ringler, C. and Zhu, T. (2009). Water for agriculture: Maintaining food security under growing scarcity. Annual Review of Environmental Resources. 34: 205-22.

Sadras, V.O (1996). Cotton responses to simulated insect damage: Radiation-use efficiency, canopy architecture and leaf nitrogen content as affected by loss of reproductive organs, Field Crops Research. 48: 199-208.

Singh, A., Singh, D. and Singh, K. (2003). Study on cotton-based crop rotation in north Indian irrigated conditions. In: Proc. World Cotton Research Conf. (WCRC-3), Cape Town, South Africa.

Singh, P. and Sri Rama, Y.V. (1989). Influence of water deficient on transpiration and radiation use efficiency of chickpea (Cicer arietinum L.), Agricultural Forecasting Meteorology. 48: 317-330.

Singh, R.P., Yesh, P. and Singh, H. (2011). Effect of organic and inorganic sources of nutrients on growth, yield and quality of Indian mustard (Brassica juncea L.) under late sown condition. Pantnagar Journal of Research. 9(2): 308-310.

Singh, V. and Deo, R. 1998. Productivity and economics of different cropping system under various levels of irrigations, Indian Journal of Agronomy. 43: 419-425.

Tripathi, M.K., Chaturvedi, S., Shukla, D.K. and Mahapata, B.S. (2010). Yield performance and quality in Indian mustard (Brassica juncea) as affected by integrated nutrient management. Indian Journal of Agronomy. 55(2): 138-142.

Zwart, S.J. and Bastiaanssen, W.G.M. (2004). Review of measured crop water productivity values for irrigated wheat, rice, cotton and maize. Agricultural Water Management. 69: 115-133. 